\title{
Isolation of plasma membranes from ram spermatozoa by a two-phase polymer system
}

\author{
N. Ivanov and Y. Profirov \\ Institute of Biology and Immunology of Reproduction and Development of Organisms, Sofia, \\ and Institute of Animal Breeding, Kostinbrod, Bulgaria
}

\begin{abstract}
Summary. The plasma membranes of ram spermatozoa were disrupted in a hypotonic EDTA medium and isolated by using a two-phase polymer system of dextran-polyethyleneglycol. The plasma membranes obtained were of a relatively high degree of purity $(\sim 70 \%)$ as judged by electron microscope observations and measurements of the marker enzymes alkaline phosphatase, ATPase and AMPase. The activity of succinate cytochrome $\mathrm{C}$ reductase, a marker of mitochondrial membranes, was very low.
\end{abstract}

\section{Introduction}

Reports in the literature of the isolation of plasma membranes from sperm cells are very limited. Morton (1968) disrupted bovine epididymal spermatozoa by using a colloid mill followed by centrifugation in a sucrose density gradient and obtained a yellow band in the $40 \%$ sucrose zone which was identified by light microscopy as cell membrane fragments possessing hexokinase activity. Zahler \& Doak (1975) treated bovine spermatozoa with a hypotonic sucrose solution, homogenized and centrifuged them in a sucrose density gradient and succeeded in isolating the outer acrosomal membranes. The uppermost band of the gradient was identified as plasma membranes on the basis of its high alkaline phosphatase activity, but was strongly contaminated by cytoplasmic droplets. Goranov, Bratanov \& Dimitrova (1975), in an investigation of antigen properties of plasma membranes, isolated a crude membrane fraction. Those investigations, however, were not directly connected with the isolation, purification and characterization of sperm plasma membranes. A detailed method for the isolation of plasma membranes of boar spermatozoa was described by Lunstra, Clegg \& Morré (1974). The spermatozoa were fragmented by low-intensity sonification and ultracentrifugation in a discontinuous sucrose gradient. The plasma membranes were identified by light and electron microscopic characteristics. Later Esbenshade \& Clegg (1976) characterized the plasma membrane proteins electrophoretically.

In all investigations listed so far, the methods employed to disrupt the cells have been physical ones such as homogenization and sonification which affect other cell structures as well, thus creating conditions for contamination of the plasma membrane preparations by membranes of other organelles. Furthermore, the technique of ultracentrifugation in sucrose density gradients requires expensive ultracentrifuges.

In the present investigation our aim was to isolate the plasma membranes of ram spermatozoa by using mild conditions of treatment. 


\section{Materials and Methods}

Preparation of the two-phase polymer system. The polymer system consisted of $5.5 \mathrm{~g}$ dextran 500 (Fluka A.G., Busch, Switzerland) and $4.2 \mathrm{~g}$ polyethyleneglycol (Fluka) dissolved in $90 \mathrm{ml}$ $0.1 \mathrm{M}$-phosphate buffer, $\mathrm{pH} 6.5$, with constant stirring. Another $100 \mathrm{ml}$ buffer were added and the mixture was transferred to a separating funnel and kept at $4^{\circ} \mathrm{C}$ until the system separated completely into two clear phases. The lower phase $(\sim 44 \mathrm{ml})$ and the upper phase $(\sim 56 \mathrm{ml})$ were placed in beakers and kept at $4^{\circ} \mathrm{C}$.

Isolation of the membranes. The semen was obtained in February-March from rams of the Friesian breed by collection into an artificial vagina. The scheme of the isolation procedure is shown in Text-fig. 1. About 5-10 min after collection each ejaculate $(0.5-1.0 \mathrm{ml})$ was centrifuged at $1200 \mathrm{~g}$ for $10 \mathrm{~min}$ at ambient temperature. The supernatant was discarded and the sperm sediment was suspended (to 40 times the volume of the ejaculate) in cold $2.5 \mathrm{mM}$-EDTA solution, adjusted to $\mathrm{pH} 7.4$ with $\mathrm{NaOH}$. The suspension was stirred in an ice bath for $30 \mathrm{~min}$, centrifuged at $2600 \mathrm{~g}$ for $10 \mathrm{~min}$ at $4^{\circ} \mathrm{C}$ and the sediment $\left(\mathrm{S}_{1}\right)$ was preserved. The supernatant was centrifuged at $9500 \mathrm{~g}$ for $15 \mathrm{~min}$ at $4^{\circ} \mathrm{C}$ and the sediment $\left(\mathrm{S}_{2}\right)$ was kept while the

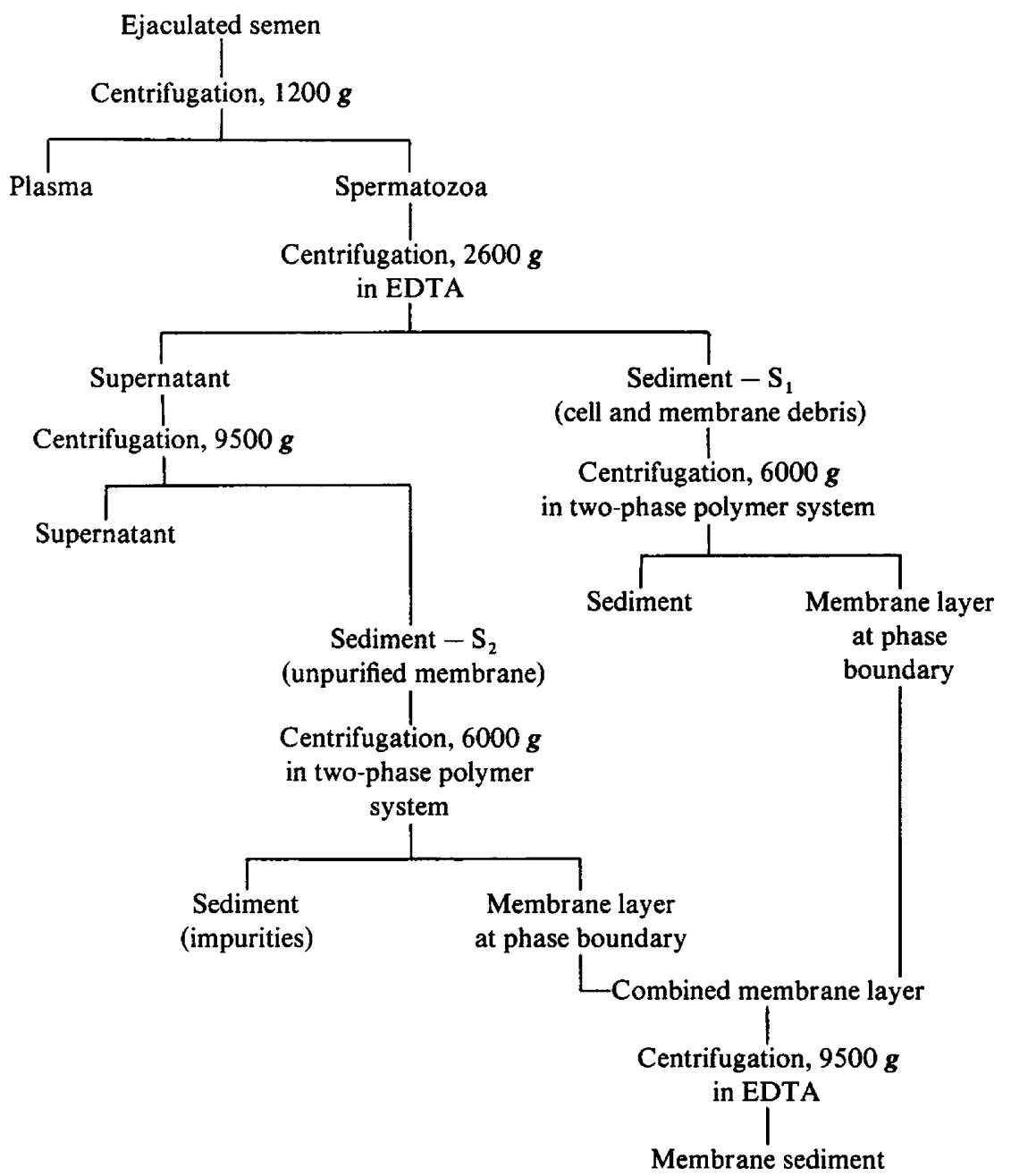

Text-fig. 1. Flow diagram of the isolation procedure for sperm plasma membranes. 
supernatant was discarded. To each sediment $\left(\mathrm{S}_{1}\right.$ and $\left.\mathrm{S}_{2}\right)$ were added $5.6 \mathrm{ml}$ of the upper phase of the polymer system. After careful mixing by successive passage into and out of a pipette with a narrow orifice, $4.4 \mathrm{ml}$ of the lower phase were added. The mixture was centrifuged at $6000 \mathrm{~g}$ for $30 \mathrm{~min}$ at $4^{\circ} \mathrm{C}$. The membranes separated at the boundary between the two phases as a distinct layer (narrower for $S_{1}$ ) and the impurities sedimented. The membrane layers from the two tubes (capacity $26 \mathrm{ml}$ ) were withdrawn by suction using a syringe (capacity $2 \mathrm{ml}$ ) with a stainless-steel needle. The membrane layers were combined, suspended twice in $20 \mathrm{ml} 2.5$ mM-EDTA solution, $\mathrm{pH} 7.4$, and centrifuged at $9500 \mathrm{~g}$ for $15 \mathrm{~min}$ at $4{ }^{\circ} \mathrm{C}$. The resulting sediment was suspended in $1 \mathrm{ml} 50 \mathrm{~mm}$-Tris- $\mathrm{HCl}, \mathrm{pH} \mathrm{7.4}$. The sediments, containing 'stripped' cells and impurities, obtained after centrifugation with the two phases were also combined and suspended in $2.5 \mathrm{~mm}$-EDTA, $\mathrm{pH} 7.4$, centrifuged at $9500 \mathrm{~g}$ for $15 \mathrm{~min}$ at $4^{\circ} \mathrm{C}$ and finally suspended in $30 \mathrm{ml} 50 \mathrm{~mm}$-Tris- $\mathrm{HCl}, \mathrm{pH} 7.4$.

Enzyme characteristics. The suspensions obtained were tested for the activities of $\mathrm{Mg}^{2+}(\mathrm{Na}$ $+\mathrm{K}$ )-ATPase (EC 3.6.1.3), 5'-AMPase (EC 3.1.3.5) and alkaline phosphatase (EC 3.1.3.1) as markers of plasma membranes, and of succinate cytochrome $C$ reductase (EC 1.3.99.1) as a marker of mitochondria and mitochondrial membrane contamination. The enzyme activity was related to $1 \mathrm{mg}$ protein. The ATPase activity was determined on the basis of liberated inorganic phosphate $\left(\mathrm{P}_{\mathrm{i}}\right)$. The sediment and membrane suspensions $(0.05-0.2 \mathrm{ml})$ containing $10-100 \mu \mathrm{g}$ protein depending upon the fraction (about $10 \mu \mathrm{g}$ from the membranes and $100 \mu \mathrm{g}$ from the sediment) were incubated for $1 \mathrm{~h}$ at $37^{\circ} \mathrm{C}$ in a medium of $50 \mathrm{~mm}-\mathrm{Tris}-\mathrm{HCl}, 5 \mathrm{~mm}-\mathrm{MgCl}_{2}, 100$

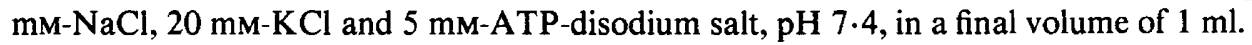

The activity of $5^{\prime}$-AMPase (5'-nucleotidase) was determined on the same principle in a medium containing a certain amount of the suspension $(30-200 \mu \mathrm{g}$ protein) in $50 \mathrm{~mm}-\mathrm{Tris}-\mathrm{HCl}$, $10 \mathrm{~mm}-\mathrm{MgCl}_{2}, 5 \mathrm{~mm}-5^{\prime}-\mathrm{AMP}, \mathrm{pH} 7 \cdot 4$, in a final volume of $1 \mathrm{ml}$.

After the incubation in an ice bath for $5 \mathrm{~min}$ the enzyme reaction was stopped by adding $0.25 \mathrm{ml}$ perchloric acid and $0.25 \mathrm{ml} 1.0 \mathrm{M}-\mathrm{KCl}$. The mixture was centrifuged at $2600 \mathrm{~g}$ for 10 min at $4^{\circ} \mathrm{C}$ and $\mathrm{P}_{\mathrm{i}}$ was determined by the method of Chen, Toribara \& Warner (1956).

The alkaline phosphatase was determined in a reaction mixture containing a certain amount of the suspension (100-200 $\mu \mathrm{g}$ protein) in a medium of $1 \mathrm{M}$-Tris and $15 \mathrm{~mm} p$ nitrophenylophosphate, $\mathrm{pH} 10 \cdot 2$, in a final volume of $2 \mathrm{ml}$. The changes in optical density were read from a kinetic curve registered at $400 \mathrm{~nm}, 25^{\circ} \mathrm{C}$, with a recording double-beam spectrophotometer (Specord UV-VIS, Carl Zeiss, Jena, GDR). The activity of succinate cytochrome $C$ reductase was determined on the basis of changes in optical density at $550 \mathrm{~nm}$ resulting from the reduction of cytochrome $\mathrm{C}$ in a mixture of a certain amount of the suspension $(0.1-0.2 \mathrm{ml}$. 100-200 $\mu \mathrm{g}$ protein, in $50 \mathrm{~mm}$-Tris-HCl, pH 7.4), $5 \mathrm{~mm}-\mathrm{KCN}, 75 \mathrm{~mm}$-sodium succinate, $0.44 \mathrm{~mm}$-cytochrome $\mathrm{C}$ and $50 \mathrm{~mm}$-phosphate buffer, $\mathrm{pH} 7.4$, in a final volume of 2 $\mathrm{ml}$. The changes in optical density were read from a kinetic curve registering the reaction velocity at $25^{\circ} \mathrm{C}$. Protein was determined with the method of Lowry, Rosebrough, Farr \& Randall (1951).

Electron microscopy. The material (spermatozoa and membrane sediment) was fixed in $2.5 \%(\mathrm{w} / \mathrm{v})$ glutaraldehyde in $0.1 \mathrm{M}$-phosphate buffer, $\mathrm{pH} 7.4$, containing $10 \%(\mathrm{w} / \mathrm{v})$ sucrose and post-fixed in $1 \%(\mathrm{w} / \mathrm{v}) \mathrm{OsO}_{4}$ in the same buffer for $2 \mathrm{~h}$. After dehydration in absolute ethanol and embedding in epoxy resin, sections were stained with uranyl acetate, followed by lead citrate (Keyhani \& Storey, 1973).

\section{Results}

The electron microscope patterns showed that sperm cells not treated with hypotonic EDTA solution were completely preserved (Pl. 1, Fig. 1). The treatment, however, stripped the spermatozoa of their membranes, without inflicting damage to the mitochondrial apparatus ( $\mathrm{Pl}$. 
1, Fig. 2). The isolated plasma membranes were predominantly of vesicular form. Nevertheless, compact formations with a non-lamellar structure were also observed, indicating contamination with material that did not originate from the plasma membranes (Pl. 1, Fig. 3).

The determinations of the marker enzymes proved a 6-11-fold higher activity of the markers in the membrane preparation compared to the total activity of the 'homogenate' (Table 1 ). There was no increase in succinate cytochrome $\mathrm{C}$ reductase.

Table 1. Enzyme activities ( $\mu \mathrm{mol} / \mathrm{h} / \mathrm{mg}$ protein) in the various fractions of treated ram spermatozoa

\begin{tabular}{|c|c|c|c|c|c|c|}
\hline Enzyme & $\begin{array}{c}\text { No. of } \\
\text { ejaculates }\end{array}$ & $\begin{array}{c}\text { Total } \\
\text { activity* }\end{array}$ & Sediment & Membranes & $\begin{array}{l}\text { Increase of } \\
\text { activity } \\
(x)\end{array}$ & $\begin{array}{l}\text { Yield of } \\
\text { the enzyme } \\
\text { (\%) }\end{array}$ \\
\hline \multicolumn{7}{|l|}{$\mathrm{Mg}^{2+}(\mathrm{Na}+\mathrm{K})$} \\
\hline APTase & 9 & $3.61 \pm 0.56$ & $2.9 \pm 0.45$ & $29.5 \pm 4.86$ & $8 \cdot 2$ & 22 \\
\hline $5^{\prime}$-AMPase & 3 & $1.74 \pm 0.13$ & $1.5 \pm 0.11$ & $10.3 \pm 0.57$ & 5.9 & 16 \\
\hline Alkaline phosphatase & 5 & $0.18 \pm 0.01$ & $0.13 \pm 0.01$ & $2 \cdot 0 \pm 0 \cdot 22$ & $11 \cdot 1$ & 30 \\
\hline Cytochrome $\mathrm{C}$ reductase & 4 & $1.66 \pm 0.45$ & $1.7 \pm 0.34$ & $0.35 \pm 0.24$ & 0.21 & 0.6 \\
\hline Protein (\%) & 7 & 100 & $97.3 \pm 0.46$ & $2.7 \pm 0.46$ & - & - \\
\hline
\end{tabular}

Values are mean \pm s.e.m. for the no. of ejaculates indicated.

* Estimated on the basis of the specific activity of the sediment and the membrane fraction as well as on their percentage ratio.

\section{Discussion}

These ultrastructural and enzymic studies show that the membranes obtained by this method were of a relatively high degree of purity. Although alkaline phosphatase activity could be partly due to contamination with the seminal plasma enzyme, absorbed to the plasma membranes, we feel, like Zahler \& Doak (1975), that it can be used as a convenient marker. The alkaline phosphatase activity and the ATPase activity showed about 11-8-fold increase, which indicated an adequate degree of membrane purification. The succinate cytochrome $\mathrm{C}$ reductase activity of the membrane fraction was far weaker and that proved a minimal mitochondria and mitochondrial membrane contamination, as supported also by the morphological data. It is possible that there was contamination by outer acrosomal membranes, but a suitable marker of acrosomal membranes to indicate the degree of contamination has not yet been found. Zahler \& Doak (1975) investigated an enzyme marker for outer acrosomal membranes of bovine spermatozoa and measured acrosin, hyaluronidase and D-L-fucosidase activity, but these were inappropriate because of low enzyme activity in the isolated membranes and a lack of enzyme build up in the latter. Since Srivastava, Munnell, Yang \& Foley (1974) showed that hypotonic treatment of ram spermatozoa affected only minimally the outer acrosomal membranes we assumed that the isolated plasma membranes in our experiments were only slightly contaminated by acrosomal membranes. Neville (1975) estimated that if there was a 15-fold purification of a membrane marker and the activity of the mitochondrial marker in the membrane preparation was 0.3 , then a purification of about $75 \%$ would be achieved. In this investigation the activity of alkaline phosphatase increased 11 -fold, that of ATPase 8-fold, and that of succinate cytochrome $\mathrm{C}$ reductase was reduced to $20 \%$, so it can be accepted that about $70 \%$ of the isolated fraction is composed of plasma membranes.

On the basis of the distribution of the enzyme activity of the membrane markers it can be calculated that the membrane yield is $16 \%$ in relation to the AMPase, $22 \%$ according to the ATPase activity and $30 \%$ for the alkaline phosphatase. However, we consider that the purity of the membrane fraction and the degree of the yield cannot be reasonably judged on the basis of the AMPase activity because although many investigators consider it a typical enzyme of the plasma membrane it has been established that in many cells it is also localized in the membrane 
PLATE 1
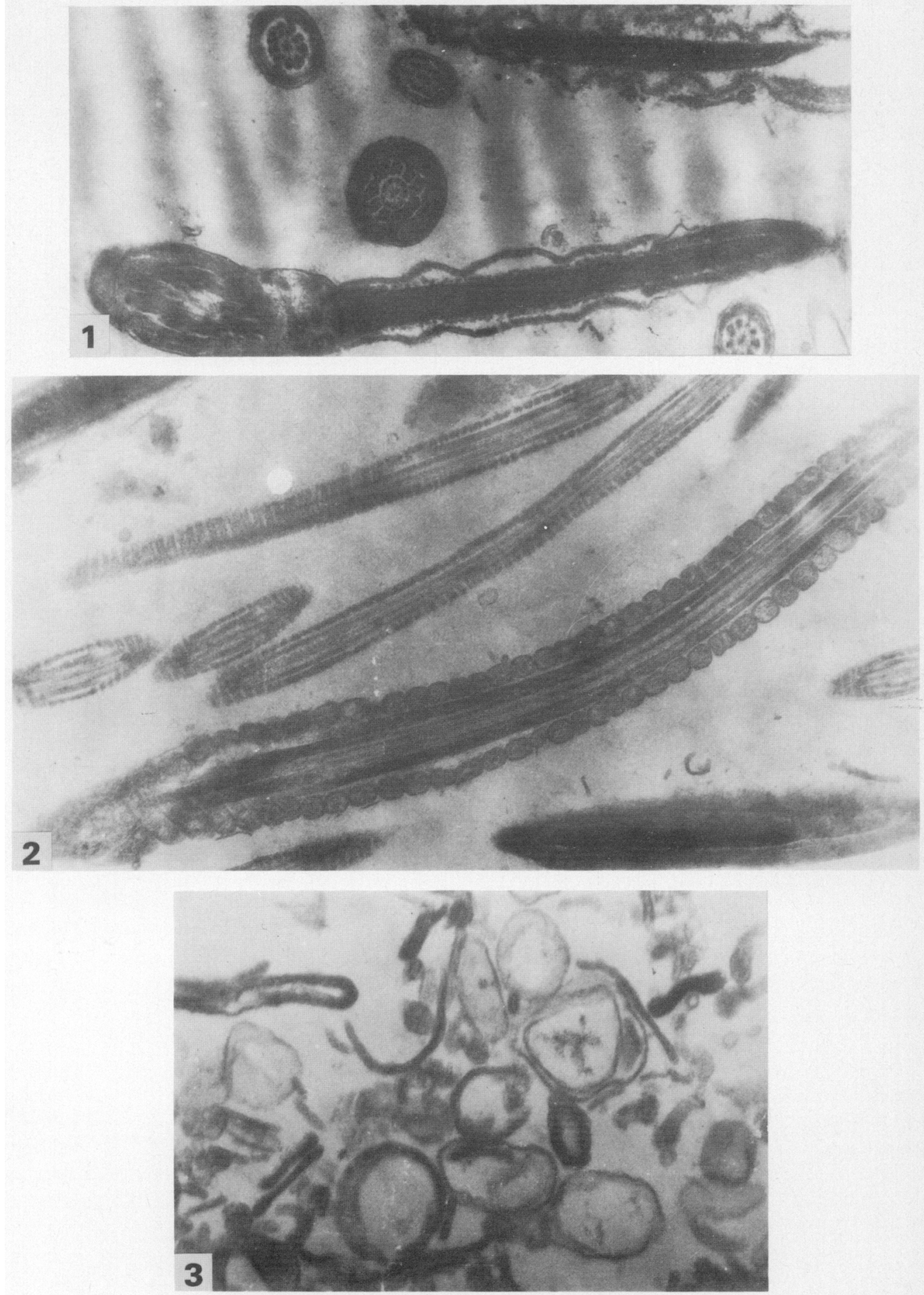

Fig. 1. Electron micrograph of an intact spermatozoon, showing the complete preservation of the plasma membrane. $\times 9000$.

Fig. 2. Electron micrograph of spermatozoa treated in EDTA hypotonic medium. The sperm membranes are stripped but the mitochondria are structurally intact. $\times 15000$.

Fig. 3. Electron micrograph of isolated membranes. $\times 18000$. 
of the different cell organelles to a considerable degree (Neville, 1975). Even the activity of the other enzyme markers cannot be used as an absolute criterion of the purity and yield, because isolated plasma membranes form closed semi-permeable vesicles most often with the outer side turned inwards so that a considerable part of the membrane enzyme might remain masked (De Pierre \& Karnovsky, 1973). We suggest that part of the sperm plasma membrane has remained attached to the cells because considerable marker enzyme activity was found in the sediment although such activity may also be due to membranes separated but 'caught' by the stripped cells and to the impurities produced by membranes sedimenting with the cell residues during their centrifugation in the two-phase system.

The $S_{1}$ membrane pellet is much smaller (about 5 times) than the $S_{2}$ pellet obtained in the present system and this stage can be omitted. There does not appear to be any difference between the membranes obtained in the $S_{1}$ and $S_{2}$ pellets for the ATPase activity at least.

Compared to existing methods, our method for the isolation of membranes by using a hypotonic EDTA medium for the disruption of plasma membranes and centrifugation in a two-phase polymer system has several advantages: (1) it does not require an ultracentrifuge; (2) the polymer aqueous solutions exert a stabilizing effect on biological structures because of the low surface tension of the boundary between the two phases $(0.001-1.0 \mu \mathrm{N} / \mathrm{cm}$ compared with $10-200 \mu \mathrm{N} / \mathrm{cm}$ for non-polymers) where the distribution is selective and the cell organelles are not damaged; (3) the separation depends not only on the size of the particles and their density but primarily on their surface properties, i.e. surface area, structure, nature and charge of the groups located on the surface, which in turn increase the selectivity of the method (Albertson, 1971).

We thank Dr Chernozemski, Cancer Research Institute, Sofia, for producing the electron micrographs.

\section{References}

Albertson, P.A. (1971) Partition of Cell Particles and Macromolecules. Almogvist \& Wiksell, Stockholm.

Chen, P.S., Toribara, T.J. \& Warner, H. (1956) Microdetermination of phosphorus. Analyt. Chem. 28, 1756-1758.

De Pierre, J.W. \& Karnovsky, M.L. (1973) Plasma membranes of mammalian cells. A review of methods for their characterization and isolation. J. Cell Biol. 56, 275-303.

Esbenshade, K.L. \& Clegg, E.D. (1976) Electrophoretic characterization of proteins in the plasma membranes of porcine spermatozoa. J. Reprod. Fert. 47, 333-337.

Goranov, I., Bratanov, M. \& Dimitrova, M. (1975) Isolation of plasma membranes from thymocytes and spermatozoa and investigation of their antigenic structure. Proc. 3rd Int. Symp. Immunol. Reproduction, Varna, pp. 199-205. Ed. K. Bratanov. Bulgarian Academy of Sciences, Sofia.

Keyhani, E. \& Storey, B.T. (1973) Energy conservation capacity and morphological integrity of mitochondria in hypotonically treated rabbit epididymal spermatozoa. Biochim. Biophys. Acta 305, 557-569.
Lowry, O.H., Rosebrough, N.J., Farr, A.L. \& Randall, R.J. (1951) Protein measurements with the folin phenol reagent. J. biol. Chem. 193, 265-275.

Lunstra, D.D., Clegg, E.D. \& Morré, D.J. (1974) Isolation of plasma membrane from porcine spermatozoa. Prep. Biochem. 4, 341-359.

Morton, B.E. (1968) A disruption and fractionation of bovine epididymal spermatozoa. $J$. Reprod. Fert. 15, 113-119.

Neville, D.M. (1975) Isolation of cell surface membrane fractions from mammalian cells and organs. In Methods in Membrane Biology. 3. Plasma Membrane, pp. 1-49. Ed. E. O. Korn. Plenum Press, New York.

Srivastava, P.N., Munnell, J.F., Yang, C.H. \& Foley, C.W. (1974) Sequential release of acrosomal membranes and acrosomal enzymes of ram spermatozoa. J. Reprod. Fert. 36, 363-372.

Zahler, W.L. \& Doak, G.A. (1975) Isolation of outer acrosomal membranes from bull sperm. Biochim. Biophys. Acta 406, 479-488.

Received 4 September 1980 